\section{The current status of sepsis research in Japan and its international comparison}

To the Editor: Toshiaki Iba*1 , Toshihiko Mayumi*2

${ }^{* 1}$ Department of Emergency and Disaster Medicine, Juntendo University

(2-1-1 Hongo, Bunkyo-ku, Tokyo 113-8421, Japan)
*2 Department of Emergency and Intensive Care Medicine, Graduate School of Medicine, Nagoya University (65 Tsurumai-cho, Showa-ku, Nagoya, Aichi 466-8550, Japan)

J Jpn Soc Intensive Care Med 2010;17:545 546.

\title{
症例の集積は敷衍的に
}

\section{編集委員長殿}

本誌 17 巻 2 号 $(2010$ 年 4 月号) に掲載されたたこつ ぼ型心筋症に関する論文1)は, refeeding syndromeに 関連して発症したと思われること, 年齢が 18 歳と若い ことが従来の報告と異なっており，興味深く拝読しま した。またこのの論文に論評を加えた石原正治氏によ るハイライト2)もよくまとまっていると思います。

しかし, 見逃してならないのは本誌 12 巻 3 号 $(2005$ 年7月号) p. 213-7に,「たこつぼ型心筋障害を呈した 巨大声带ポリープの 1 症例」として症例報告3)があり， 同時に 17 巻 2 号のハイライト執筆者と同じ施設の 栗栖智氏が「たこつぼ型心筋障害：救急集中治療医へ の啓発」4)としてハイライトを執筆されていることで あります。ハイライトは, 前回に取り上げた時と比較 して当該分野でどの程度進展をみているかを中心に論 じることを，執筆者に依頼すべきであると考えます。 どの雑誌もいわゆるImpact Factorを上げるために, 自身の雑誌に揭載された関連論文は必要に応じて引用 するように，具体的に論文名をあげて著者に注意を喚 起する程度のことは, Editorが行っております（本誌 がたとえMEDLINEに収載されていないにしても)。
しかし，今回の掲載論文では， 5 年前の本誌に掲載さ れた論文について一言も触れずに無視しております。 編集委員会の見解を扮伺いする次第です。

\section{今井 孝祐}

前 東京医科歯科大学大学院医歯学総合研究科救命救急 医学教授

（₹ 113-8510＼cjkstart東京都文京区湯島 1-5-45）

\section{文 献}

1) 松本充弘, 平尾 収, 木岡秀隆, 他. Refeeding syndrome にたこつぼ型心筋症を合併したanorexia nervosaの1例. 日集中医誌 2010;17:185-9.

2) 石原正治. たこつぼ心筋障害． 日集中医誌 2010;17:133-5.

3) 斉藤朗子, 依田建吾, 平田 学, 他. たこつぼ型心筋障害 を呈した巨大声帯ポリープの1症例．日集中医誌 2005;12 213-7.

4) 栗栖 智. たこつぼ型心筋障害 : 救急集中治療医への啓発. 日集中医誌 2005;12:186-8.

受付日 2010 年 4 月 23 日 採択日 2010 年 5 月 2 日 
今井孝祐先生 (編集委員長回答)

日本集中治療医学会機関誌編集委員会へ貴重なご意 見を賜りましたことを御礼申し上げます。ご意見の主 旨は以下の二点と拝察し, ご回答申し上げます。

1) ハイライト執筆のあり方について

ハイライトは対象論文内容の主題を専門家に最新の 知見に基づき平易に解説していただき，日本集中治療 学会会員を啓蒙することを目的としております。さら に, 当該論文を取り上げ，その内容に関して専門的か つ建設的に批評していただくことにより, 論文著者を 啓発することも目的の一つです。今回ご指摘賜りまし た類似主題論文のハイライトに抒きましては, 前回に 取り上げた時と比較して当該分野でどのような進展が 見られたのかについても論じていただくようお願いす ることと致します。

\section{2) 機関誌掲載論文の引用について}

日本集中治療医学会雑誌はいまだ発展途上であり, 解決すべき問題点が山積しております。今回ご指摘賜 りました, 機関誌掲載論文の可及的な引用に関して著 者へ注意を喚起することもその一つと認識しておりま す。昨年から機関誌はJ-STAGE (Japan Science Technology Information Aggregator, Electronic)を 通じて保存・管理され，その閲覽が容易になりました。 J-STAGEの応用により，今後はいただいたご意見に
関して,より注意深い対応が可能になるかと存じます。 今回のご意見を参考に, 機関誌編集委員会一同, より良い機関誌編集に倍旧の努力をする所存でござい ます。今後とも機関誌編集委員会へのご指導・ご鞭撻 の程, どうぞよろしく颃願い申し上げます。

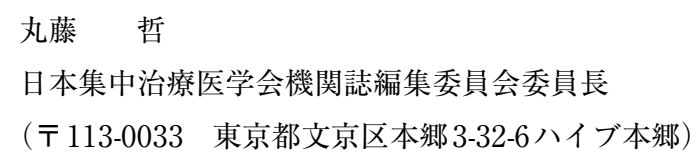

\section{Accumulation of valuable cases in a grow- ing way}

To the Editor: Takasuke Imai

Ex-professor, Department of Critical Care Medicine, Tokyo Medical and Dental University

(1-5-45 Yushima, Bunkyo-ku, Tokyo 113-8510, Japan)

\section{In Reply:}

Satoshi Gando

Editor-in-Chief, Journal of the Japanese Society of Intensive Care Medicine

(3-32-6 Haive Hongo, Hongo, Bunkyo-ku, Tokyo 113-0033, Japan)

J Jpn Soc Intensive Care Med 2010;17:546 547. 